\title{
Stability of 'mangaba' pulp powder obtained by freeze drying
}

\author{
Juliana Conegero ${ }^{1}$, Luciana C. Ribeiro ${ }^{2}$, José M. C. da $\operatorname{Costa}^{2} \&$ Antonio R. G. Monteiro $^{1}$ \\ ${ }^{1}$ Universidade Estadual de Maringá/Centro de Ciências Agrárias/Departamento de Ciência e Tecnologia de Alimentos. Maringá, PR. E-mail: juconegero@gmail.com \\ (Corresponding author); antoniorgm@gmail.com \\ ${ }^{2}$ Universidade Federal do Ceará/Centro de Ciências Agrárias/Departamento de Ciência e Tecnologia de Alimentos. Fortaleza, CE. E-mail: ribeirolc@gmail.com; \\ correiacostaufc@gmail.com
}

\section{Key words:}

cold drying

Hancornia speciosa Gomes storage

\begin{abstract}
A B S T R A C T
This work examined the stability of lyophilized 'mangaba' pulp powder, rolled and packaged in plastic containers, with and without vacuum during 90 days of storage under room temperature, with evaluation of the parameters every 15 days. Analyses of ascorbic acid concentration, $\mathrm{pH}$, color and water activity were carried out. It was found that ascorbic acid remained in accordance with the standards specified for daily consumption according to the Brazilian legislation in all analyzed packages, with preservation of stability in the laminated package with vacuum, which was also effective in maintaining water activity, which contributes to better stability of the product.
\end{abstract}

Palavras-chave: secagem a frio Hancornia speciosa Gomes armazenamento

\section{Estabilidade do pó da polpa de mangaba obtido por liofilização}

\section{R E S U M O}

A conservação de produtos desidratados, como aqueles obtidos por liofilização, torna necessária a avaliação das características físico-químicas do produto durante o armazenamento. Foi analisada a estabilidade da mangaba em pó obtida por secagem, através de liofilização, acondicionada em embalagens laminadas e plásticas, com e sem vácuo, durante 90 dias de armazenamento em temperatura ambiente. A cada 15 dias de armazenamento foram realizadas as análises de concentração de ácido ascórbico, $\mathrm{pH}$, atividade de água e cor. Verificou-se que o ácido ascórbico se manteve de acordo com os padrões indicados para consumo diário, conforme a legislação brasileira em todas as embalagens analisadas, com preservação da estabilidade pela embalagem laminada com vácuo, que também foi eficaz na manutenção da atividade de água, o que contribui para melhor estabilidade do produto. 


\section{INTRODUCTION}

Mangabeira (Hancornia speciosa Gomes) is a tree native to Brazil, belonging to the Apocynaceae family, which has medium size and height from 5 to $10 \mathrm{~m}$, and its fruit is the 'mangaba' (Campos et al., 2011).

'Mangaba' has high nutritional value and, according to Almeida et al. (2016), can be considered as excellent source of vitamin C. According to Santos et al. (2009), the fruit also has, as characteristics, excellent physical properties, aroma and taste. Perfeito et al. (2015) point out that 'mangaba' is highly perishable, which makes viable the use of dehydration through adequate methods to prolong its storage.

Lyophilization is a dehydration method used in food industry. This process enables a better preservation of the characteristics of the product, maintenance of final quality and increase in food's useful life due to the reduction in the water content and consequent decrease in the moisture of the product (Sanjinez-Argandoña et al., 2011). The principle used for it is the sublimation, i.e., the change from solid state directly to the gaseous state, using vacuum and low temperature in the dehydration process (Oikonomopoulou et al., 2011). Storage in adequate packages becomes necessary in lyophilized products, for the stability during storage.

The package must have a barrier against moisture and must be able to prevent the transfer of oxygen to the product, whose quality attributes must be monitored and evaluated to guarantee safety and acceptance (Jangam et al., 2010).

The present study aimed to evaluate the stability of 'mangaba' pulp powder obtained through lyophilization and stored in laminated and plastic packages, with and without vacuum, through physical-chemical analyses, for the period of 90 days.

\section{Material ANd Methods}

'Mangaba' pulps were purchased in the industrial zone of Natal-RN, Brazil, and transferred under refrigeration to the Laboratory of Food Quality Control and Drying of the Federal University of Ceará, Pici Campus, Fortaleza-CE, where they were stored under freezing $\left(-18^{\circ} \mathrm{C}\right)$ in a vertical freezer.

The pulps were thawed under temperature of refrigeration for later addition of maltodextrin DE 20 (dextrose equivalent), at concentration of $30 \%$, in a mixer at $14000 \mathrm{rpm}$ for $5 \mathrm{~min}$, until complete homogenization. Subsequently, the pulps were arranged on stainless-steel tray with diameter of $18 \mathrm{~cm}$ and thickness of $2.5 \mathrm{~cm}$, for freezing in ultra-freezer (CL 90-40 $\mathrm{V}$ ), for the period of $24 \mathrm{~h}$ at $38 \pm 1{ }^{\circ} \mathrm{C}$. The frozen product was taken to the lyophilizer (Liotop, model L101), for the dehydration process also for $24 \mathrm{~h}$, reaching final pressure of $17 \mu \mathrm{Hg}$ and condenser temperature of $-52^{\circ} \mathrm{C}$.

The dehydrated product was ground in knife mill (Marconi, model 048), to obtain the product in powder. Seven lyophilizations were made to obtain the product in powder in amount sufficient for the analyses during the proposed period.

The lyophilized 'mangaba' pulp powder was stored in laminated and plastic packages at room temperature and protected from light. Laminated packages consisted of aluminum/PET + adhesive $(\mathrm{ADH})+$ aluminum $+\mathrm{ADH}+$ PE film, with thickness of $970 \mu \mathrm{m}$. Plastic packages consisted of polyethylene terephthalate $(\mathrm{PET})+$ polymer/PET + polyethylene, with thickness of $970 \mu \mathrm{m}$. The packages were sealed with and without vacuum.

The analyses are described below and were performed at the time zero (after processing) and every 15 days, totaling 90 days. Ascorbic acid was determined through titration with 2,6 dichloroindophenol, according to the methodology of Strohecker \& Henninger (1967). The pH was determined according to the methodology of IAL (2008). Water activity was determined in an AquaLab $4 \mathrm{TEV}$ device, at $25^{\circ} \mathrm{C}$, calibrated with distilled water. Color was determined using a colorimeter Konica Minolta CR-410, through the CIE system, obtaining the parameters $\mathrm{L}^{\star}, \mathrm{a}^{*}$ and $\mathrm{b}^{\star}$, where $\mathrm{L}^{\star}$ represents luminosity $\left(\mathrm{L}^{*}=0\right.$ black and $\mathrm{L}^{\star}=100$ white) while $\mathrm{a}^{\star}$ and $\mathrm{b}^{\star}$ are chromaticity $\left(+a^{\star}\right.$ red, $-a^{\star}$ green, $+b^{\star}$ yellow and $-b^{\star}$ blue $)$ (Carvalho et al., 2017)

The experiments were performed in triplicate and the statistical evaluation consisted in analysis of variance (ANOVA) and Tukey test, at 0.05 probability level, using the program Statistica 7.0 (Statsoft Co., 2007).

\section{Results AND Discussion}

During the storage, the aspect of powder was maintained by the studied packages, except the plastic package with vacuum. After 75 days of storage, it was not possible to evaluate the samples stored in this package due to the great agglomeration of the particles. This phenomenon is attributed to the water absorption on the surface of the particles, forming a saturated solution, thus making the particles sticky, compromising handling and causing the phenomenon of caking, or agglomeration of the particles (Goula \& Adamopoulos, 2008).

The results for the ascorbic acid of the powder are presented in Table 1, which shows a significant reduction over time in the plastic package without vacuum (PSV) at 90 days of storage and in laminated package without vacuum (LSV) and plastic with vacuum (PCV) at 75 days, which demonstrates stability promoted by the package. Teixeira \& Monteiro (2006) claimed that the package influences the quality of the products and must maintain them protected from oxygen, light and humidity, since these factors may lead to sensory changes and loss of vitamins. Still according to the authors, oxygen may be present dissolved in the product, in the free space of the package or it may permeate through the package material, causing, as adverse effects, the degradation of the ascorbic acid. Sousa et al. (2016) report significant difference at 30 and 45 days of storage for vacuum-sealed laminated and plastic packages, respectively, in the storage of atomized cashew juice.

Among the analyzed packages, there was an accentuated reduction of $15 \%$ at 75 days of storage in $\mathrm{PCV}$, which demonstrates in the present study the influence of the use of sealing without vacuum in the plastic package for the preservation of ascorbic acid. Moreira et al. (2011) cite the 
Table 1. Stability of lyophilized 'mangaba' pulp powder stored in different packages regarding the content of ascorbic acid

\begin{tabular}{ccccc}
\hline \multirow{2}{*}{$\begin{array}{c}\text { (dime } \\
\text { (days) }\end{array}$} & \multicolumn{4}{c}{ Packages } \\
\cline { 2 - 5 } 0 & $55.98 \mathrm{Aa} \pm 2.84$ & LSV & PCV & PSV \\
15 & $56,04 \mathrm{Aa} \pm 1.92$ & $55.98 \mathrm{Ca} \pm 2.84$ & $55.98 \mathrm{Ba} \pm 2.84$ & $55.98 \mathrm{Ba} \pm 2.84$ \\
30 & $55.84 \mathrm{Aa} \pm 1.18$ & $54.39 \mathrm{Ca} \pm 0.90$ & $55.25 \mathrm{Ba} \pm 0.51$ & $53.92 \mathrm{Ba} \pm 2.88$ \\
45 & $55.95 \mathrm{Aa} \pm 0.51$ & $54.67 \mathrm{BCab} \pm 0.66$ & $54.76 \mathrm{Ba} \pm 0.53$ & $53.99 \mathrm{Ba} \pm 0.27$ \\
60 & $54.30 \mathrm{Aa} \pm 0.66$ & $53.66 \mathrm{BCa} \pm 1.68$ & $53.99 \mathrm{Bb} \pm 0.49$ & $55.07 \mathrm{Bab} \pm 0.47$ \\
75 & $51.57 \mathrm{Aab} \pm 2.54$ & $49.12 \mathrm{Aab} \pm 0.57$ & $52.21 \mathrm{Ba} \pm 0.55$ & $53.90 \mathrm{Ba} \pm 0.90$ \\
90 & $50.58 \mathrm{Aa} \pm 2.85$ & $50.24 \mathrm{ABa} \pm 2.27$ & $47.58 \mathrm{Ab} \pm 1.97$ & $53.39 \mathrm{Ba} \pm 1.06$ \\
& & n.d. & $47.97 \mathrm{Aa} \pm 0.94$ \\
\hline
\end{tabular}

LCV - Laminated package with vacuum; LSV - Laminated package without vacuum; PCV - Plastic package with vacuum; PSV - Plastic package without vacuum; n.d.- Not determined; Means followed by the same letter do not differ $(p \geq 0.05)$ by Tukey test, equal uppercase letters do not differ in the column and equal lowercase letters do not differ in the row

influence of the polyethylene package in the reduction of ascorbic acid in the storage of dehydrated cupuaçu. Oliveira et al. (2015a) cite that, besides the influence of the type of package, the ascorbic acid content may be altered by $\mathrm{pH}$, water content, oxygen inside the package, temperature and relative humidity of storage.

Among the analyzed packages, laminated with vacuum (LCV) and PCV were significantly different only at 45 days, while PSV and PCV were significantly different at 75 days, without significant alteration between the packages at the final time. In the entire period of the present study, except at 90 days of storage in PCV, the product showed ascorbic acid content above the recommended daily dose of $45 \mathrm{mg} 100$ $\mathrm{g}^{-1}$, according to BRASIL (2005), being considered as source of vitamin C. At 90 days of storage in the PCV package, the product did not show physical conditions for the analyses of the present study.

Regarding the $\mathrm{pH}$, in the LSV package, there was significant alteration in relation to the initial time, in all periods of storage, with increase of $1.92 \%$ in the period of 90 days (Table 2).

For the storage in LCV package, there was alteration only at 15,30 and 60 days and increase of $0.64 \%$ in $\mathrm{pH}$, because in the final time this increase is not harmful to the product, since it can be classified, according to Gava (2009), as acidic
( $\mathrm{pH}<4.0$ ), which inhibits the growth of microorganisms. In the study on viability of cupuaçu pulp dehydrated for 90 days, Moreira et al. (2011) reported values very similar between the beginning and end of the period.

Between the laminated packages, the $\mathrm{pH}$ does not differ statistically at 15 days and at 60 and 75 days of storage. As to the plastic packages, there is a significant difference between PCV and PSV, at 30 and 75 days of storage, which demonstrates that there was no significant alteration resulting from the use of vacuum in most of the analyzed period.

At 75 days of storage in PCV and at 90 days in PSV, there were increments of 1.60 and $0.32 \%$, respectively, in relation to the initial time, demonstrating higher efficiency of PSV to maintain the $\mathrm{pH}$, in the present study. Among the four analyzed packages, only LSV showed statistical difference at the final time, at 90 days of storage, in relation to the initial time, at time 0 , which indicates stability of the product. All $\mathrm{pH}$ values are not within the range of 5-7, which allows enzymatic darkening in most plants, according to Breda et al. (2012).

In the analysis of water activity (Table 3), there was an increment at the final time in the packages, with significant difference at 15 days of storage. Breda et al. (2012) also observed increase in water activity over time, in the storage of guavira powder.

Table 2. Stability of lyophilized 'mangaba' pulp powder stored in different packages regarding the $\mathrm{pH}$

\begin{tabular}{|c|c|c|c|c|}
\hline \multirow{2}{*}{$\begin{array}{l}\text { Time } \\
\text { (days) }\end{array}$} & \multicolumn{4}{|c|}{ Packages } \\
\hline & LCV & LSV & PCV & PSV \\
\hline 0 & $3.12 \mathrm{Aa} \pm 0.00$ & $3.12 \mathrm{Aa} \pm 0.00$ & $3.12 \mathrm{Ba} \pm 0.00$ & $3.12 \mathrm{Ca} \pm 0.00$ \\
\hline 15 & $3.03 \mathrm{Db} \pm 0.51$ & $3.18 \mathrm{Dab} \pm 0.00$ & $3.33 \mathrm{Aa} \pm 0.14$ & $3.14 \mathrm{Cab} \pm 0.01$ \\
\hline 30 & $3.25 \mathrm{Ca} \pm 0.00$ & $3.15 \mathrm{Cb} \pm 0.00$ & $3.16 \mathrm{Bb} \pm 0.00$ & $3.25 \mathrm{Aa} \pm 0.00$ \\
\hline 45 & $3.17 \mathrm{BAa} \pm 0.00$ & $3.16 \mathrm{BCb} \pm 0.00$ & $3.15 \mathrm{Bb} \pm 0.00$ & $3.15 \mathrm{Cb} \pm 0.00$ \\
\hline 60 & $3.19 \mathrm{BCab} \pm 0.00$ & $3.18 \mathrm{Db} \pm 0.00$ & $3.21 \mathrm{Aba} \pm 0.01$ & $3.19 \mathrm{Bab} \pm 0.01$ \\
\hline 75 & $3.17 \mathrm{ABb} \pm 0.00$ & $3.17 \mathrm{BDb} \pm 0.00$ & $3.17 \mathrm{Ba} \pm 0.01$ & $3.13 \mathrm{Cb} \pm 0.00$ \\
\hline 90 & $3.14 \mathrm{ABb} \pm 0.01$ & $3.18 \mathrm{Da} \pm 0.01$ & n.d. & $3.13 \mathrm{Cb} \pm 0.00$ \\
\hline
\end{tabular}

LCV - Laminated package with vacuum; LSV - Laminated package without vacuum; PCV - Plastic package with vacuum; PSV - Plastic package without vacuum; n.d.- Not determined; Means followed by the same letter do not differ $(p \geq 0.05)$ by Tukey test, equal uppercase letters do not differ in the column and equal lowercase letters do not differ in the row

Table 3. Stability of lyophilized 'mangaba' pulp powder stored in different packages regarding water activity

\begin{tabular}{ccccc}
\hline $\begin{array}{c}\text { Time } \\
\text { (days) }\end{array}$ & LCV & LSV & Packages & \\
\cline { 2 - 5 } & $0.162 \mathrm{Ba} \pm 0.00$ & $0.162 \mathrm{Ca} \pm 0.00$ & $0.162 \mathrm{Ca} \pm 0.00$ & $0.162 \mathrm{Ca} \pm 0.00$ \\
15 & $0.283 \mathrm{Dc} \pm 0.01$ & $0.276 \mathrm{Bc} \pm 0.00$ & $0.234 \mathrm{Bb} \pm 0.00$ & $0.320 \mathrm{Da} \pm 0.01$ \\
30 & $0.244 \mathrm{Ac} \pm 0.01$ & $0.340 \mathrm{Db} \pm 0.05$ & $0.310 \mathrm{Aa} \pm 0.00$ & $0.310 \mathrm{Ba} \pm 0.00$ \\
45 & $0.306 \mathrm{Db} \pm 0.00$ & $0.339 \mathrm{Dc} \pm 0.01$ & $0.384 \mathrm{Da} \pm 0.00$ & $0.334 \mathrm{Dc} \pm 0.00$ \\
60 & $0.331 \mathrm{Dc} \pm 0.00$ & $0.342 \mathrm{Db} \pm 0.00$ & $0.304 \mathrm{Ad} \pm 0.00$ & $0.377 \mathrm{Aa} \pm 0,00$ \\
75 & $0.366 \mathrm{Cb} \pm 0.00$ & $0.360 \mathrm{Db} \pm 0.01$ & $0.409 \mathrm{Da} \pm 0.00$ & $0.409 \mathrm{Aa} \pm 0.00$ \\
90 & $0.368 \mathrm{Cb} \pm 0.00$ & $0.474 \mathrm{Aa} \pm 0.00$ & n.d. & $0.479 \mathrm{Ea} \pm 0.36$ \\
\hline
\end{tabular}

LCV - Laminated package with vacuum; LSV - Laminated package without vacuum; PCV - Plastic package with vacuum; PSV - Plastic package without vacuum; n.d.- Not determined; Means followed by the same letter do not differ $(p \geq 0.05)$ by Tukey test, equal uppercase letters do not differ in the column and equal lowercase letters do not differ in the row 
Laminated packages with and without vacuum remained statistically unaltered only at 15 and 75 days of storage. At the end of the analysis period, there was significant alteration between the packages sealed with and without vacuum, which demonstrates the necessity of using vacuum for better maintenance of water activity, and LCV has a final mean value lower than those of LSV and PSV.

The laminated package with vacuum also showed mean value lower than 0.4, which, according to the Food and Agriculture Organization (FAO, 1995), prevents the phenomenon of caking in dehydrated products stored at room temperature. Oliveira et al. (2015b), in the storage of lyophilized macaúba palm, in three different types of package, observed that the laminated package with vacuum was the most effective to maintain water activity of the product, corroborating with the present study.

Only in PSV, the luminosity of lyophilized 'mangaba' pulp powder did not show significant alteration between the final and initial times, with maintenance of this parameter, as presented in Table 4. In LCV, LSV and PCV, there was a decrease in the values over time, but much inferior to the reduction reported in other studies, such as Alexandre et al. (2014), who studied the stability of pitanga powder. In the study on the stability of the stored powder, the reduction of luminosity, with loss of brightness, allows to analyze if there is darkening in the product resulting, probably, from the gain of moisture and/or loss of carotenoids and ascorbic acid during storage or even from a reaction of non-enzymatic nature, which in processed foods is associated with the storage conditions, which may lead to the occurrence of Maillard reaction (Ribeiro, 2014).

The packages PCV and PSV remained statistically unaltered in relation to one another at 45 days, and LCV and LSV at 90 days, demonstrating in most of the analyzed period the significant variation between the packages, which indicates the influence of the type of package and sealing used.

Table 5 shows the values of green intensity during the storage of lyophilized 'mangaba' pulp powder. The negative values (trend to green) may be related to the addition of maltodextrin because, according to Tonon et al. (2009), the addition of this drying adjuvant favors the reduction of this parameter.

In all packages, there was an increase of this variable and significant alteration at the final time in relation to the initial time of storage with oscillations, although stability was observed between certain times. LCV and PSV showed increments of 7.25 and 5.81\%, respectively. Lisbôa et al. (2012) report the increase in the intensity of the coordinate $-\mathrm{a}^{*}$ during the storage of prickly pear powder, related to the temperature of the environment and also with darkening of the sample.

Some packages remained unaltered in relation to one another; for example, at 45 days, LCV, LSV and PCV did not differ statistically. Only in the final time of storage, there was significant alteration between all packages.

The results presented in Table 6, relative to yellow intensity, during the storage of the powder, demonstrated that there was no statistical difference at the final time of 90 days only for LSV and at 75 days for PCV, in relation to the initial time. Among the packages, PSV and LSV remained statistically unaltered at 45 days and LCV and LSV at 75 days.

There were reductions of 4.16 and $9.29 \%$ in this parameter in LCV and PSV, respectively, with significant alteration at the final time of storage. Oliveira et al. (2015b) cite the laminated package with vacuum as more efficient to maintain the yellow color in the lyophilized macaúba pulp. Lisbôa et al. (2012) observed reduction greater than that of the present study, from 17 to $19 \%$ in prickly pear powder at $40{ }^{\circ} \mathrm{C}$, stored in laminated package.

Table 4. Stability of lyophilized 'mangaba' pulp powder stored in different packages regarding luminosity, $\mathrm{L}^{*}$

\begin{tabular}{ccccc}
\hline $\begin{array}{c}\text { Time } \\
\text { (days) }\end{array}$ & \multicolumn{4}{c}{ Packages } \\
\cline { 2 - 5 } 0 & $62.80 \mathrm{Da} \pm 0.01$ & $62.80 \mathrm{Ca} \pm 0.01$ & $62.80 \mathrm{Da} \pm 0.01$ & PSV \\
15 & $60.63 \mathrm{Gc} \pm 0.06$ & $59.66 \mathrm{Bd} \pm 0.03$ & $63.79 \mathrm{Ba} \pm 0.00$ & $62.80 \mathrm{Da} \pm 0.01$ \\
30 & $63.07 \mathrm{Bd} \pm 0.01$ & $63.21 \mathrm{Cc} \pm 0.01$ & $63.85 \mathrm{Aa} \pm 0.01$ & $63.49 \mathrm{Ab} \pm 0.01$ \\
45 & $62.96 \mathrm{Cb} \pm 0.01$ & $61.52 \mathrm{Aa} \pm 0.58$ & $62.48 \mathrm{~Eb} \pm 0.00$ & $62.91 \mathrm{Db} \pm 0.01$ \\
60 & $62.52 \mathrm{~Eb} \pm 0.00$ & $60.09 \mathrm{Bd} \pm 0.01$ & $62.70 \mathrm{Ca} \pm 0.01$ & $61.42 \mathrm{Bc} \pm 0.09$ \\
75 & $63.21 \mathrm{Aa} \pm 0.00$ & $63.00 \mathrm{ACc} \pm 0.00$ & $62.71 \mathrm{Cb} \pm 0.01$ & $61.03 \mathrm{Cd} \pm 0.03$ \\
90 & $61.23 \mathrm{Fb} \pm 0.01$ & $61.30 \mathrm{Ab} \pm 0.00$ & $\mathrm{n} . \mathrm{d}$. & $62.81 \mathrm{Da} \pm 0.11$ \\
\hline
\end{tabular}

LCV - Laminated package with vacuum; LSV - Laminated package without vacuum; PCV - Plastic package with vacuum; PSV - Plastic package without vacuum; n.d.- Not determined; Means followed by the same letter do not differ $(p \geq 0.05$ ) by Tukey test, equal uppercase letters do not differ in the column and equal lowercase letters do not differ in the row

Table 5. Stability of lyophilized 'mangaba' pulp powder stored in different packages regarding green intensity, a*

\begin{tabular}{ccccc}
\hline $\begin{array}{c}\text { Time } \\
\text { (days) }\end{array}$ & LCV & LSV & Packages & PSV \\
\cline { 2 - 5 } & $-2.58 \mathrm{Ca} \pm 0.01$ & $-2.58 \mathrm{Ca} \pm 0.01$ & $-2.58 \mathrm{Ca} \pm 0.01$ & $-2.58 \mathrm{Ca} \pm 0.01$ \\
15 & $-2.38 \mathrm{Dc} \pm 0.00$ & $-2.37 \mathrm{Da} \pm 0.01$ & $-2.61 \mathrm{Db} \pm 0.00$ & $-2.38 \mathrm{Ac} \pm 0.01$ \\
30 & $-2.54 \mathrm{Bb} \pm 0.00$ & $-2.46 \mathrm{Bc} \pm 0.01$ & $-2.48 \mathrm{Ac} \pm 0.00$ & $-2.51 \mathrm{Ba} \pm 0.01$ \\
45 & $-2.37 \mathrm{Db} \pm 0.00$ & $-2.36 \mathrm{Ab} \pm 0.00$ & $-2.36 \mathrm{Bb} \pm 0.01$ & $-2.41 \mathrm{Da} \pm 0.00$ \\
60 & $-2.48 \mathrm{Ab} \pm 0.01$ & $-2.16 \mathrm{Ec} \pm 0.00$ & $-2.45 \mathrm{Ab} \pm 0.00$ & $-2.28 \mathrm{Ea} \pm 0.01$ \\
75 & $-2.34 \mathrm{Ec} \pm 0.00$ & $-2.34 \mathrm{Ac} \pm 0.00$ & $-2.30 \mathrm{Bb} \pm 0.01$ & $-2.19 \mathrm{Fa} \pm 0.00$ \\
90 & $-2.38 \mathrm{Db} \pm 0.01$ & $-2.29 \mathrm{Da} \pm 0.00$ & n.d. & $-2.43 \mathrm{Dc} \pm 0.01$ \\
\hline
\end{tabular}

LCV - Laminated package with vacuum; LSV - Laminated package without vacuum; PCV - Plastic package with vacuum; PSV - Plastic package without vacuum; n.d.- Not determined; Means followed by the same letter do not differ $(p \geq 0.05$ ) by Tukey test, equal uppercase letters do not differ in the column and equal lowercase letters do not differ in the row 
Table 6. Stability of lyophilized 'mangaba' pulp powder stored in different packages regarding yellow intensity, b*

\begin{tabular}{crrrr}
\hline \multirow{2}{*}{$\begin{array}{c}\text { Time } \\
\text { (days) }\end{array}$} & \multicolumn{4}{c}{ Packages } \\
\cline { 2 - 5 } & \multicolumn{1}{c}{ LCV } & \multicolumn{1}{c}{ LSV } & PCV & PSV \\
15 & $10.33 \mathrm{Ea} \pm 0.01$ & $10.33 \mathrm{Fa} \pm 0.01$ & $10.33 \mathrm{Ca} \pm 0.01$ & $10.33 \mathrm{Aa} \pm 0.01$ \\
30 & $9.84 \mathrm{Ca} \pm 0.02$ & $9.15 \mathrm{Ec} \pm 0.00$ & $10.18 \mathrm{Dd} \pm 0.00$ & $9.28 \mathrm{~Eb} \pm 0.01$ \\
45 & $10.08 \mathrm{Ab} \pm 0.01$ & $10.23 \mathrm{Bd} \pm 0.00$ & $10.13 \mathrm{Ea} \pm 0.00$ & $10.00 \mathrm{Fc} \pm 0.00$ \\
60 & $10.34 \mathrm{~Eb} \pm 0.00$ & $10.09 \mathrm{Cc} \pm 0.01$ & $10.74 \mathrm{Aa} \pm 0.00$ & $10.07 \mathrm{Fc} \pm 0.00$ \\
75 & $9.51 \mathrm{Dc} \pm 0.00$ & $9.21 \mathrm{Db} \pm 0.01$ & $9.36 \mathrm{Fa} \pm 0.01$ & $9.53 \mathrm{Cc} \pm 0.05$ \\
90 & $10.34 \mathrm{Ec} \pm 0.01$ & $10.34 \mathrm{Fc} \pm 0.01$ & $10.39 \mathrm{Ca} \pm 0.01$ & $9.66 \mathrm{Bb} \pm 0.01$ \\
& $9.90 \mathrm{Ba} \pm 0.02$ & $10.32 \mathrm{Fb} \pm 0.00$ & $n . d$. & $9.37 \mathrm{Da} \pm 0.04$ \\
\hline
\end{tabular}

LCV - Laminated package with vacuum; LSV - Laminated package without vacuum; PCV - Plastic package with vacuum; PSV - Plastic package without vacuum; n.d.- Not determined; Means followed by the same letter do not differ $(p \geq 0.05$ ) by Tukey test, equal uppercase letters do not differ in the column and equal lowercase letters do not differ in the row

\section{Conclusions}

1. The physical-chemical parameters of 'mangaba' powder exhibit stability during the storage of 90 days and only the plastic package with vacuum did not allow the maintenance of the powder characteristic, during the entire storage period.

2. The concentrations of ascorbic acid remain within the standards required by the Brazilian legislation in all packages along the studied storage period, and the laminated package with vacuum is the most effective in the preservation of ascorbic acid concentration and water activity, which allows better conservation of the product in comparison to the other analyzed packages.

\section{Literature Cited}

Alexandre, H. V.; Figueirêdo, R. M. F. de; Queiroz, A. J. de M.; Oliveira, E. N. A. de. Armazenamento de pitanga em pó. Comunicata Scientiae, v.5, p.83-91, 2014.

Almeida, A. B. da S.; Ferreira, M. A. C.; Barbosa, T. A.; Siqueira, A. P. S.; Souza, E. R. B. de. Elaboração e avaliação sensorial de sorvete diet e sem lactose de mangaba endêmica do Cerrado. Revista de Agricultura Neotropical, v.3, p.38-41, 2016.

Breda, C. A.; Sanjinez-Argandoña, E. J.; Correia, C. de A. C. Shelf life of powdered Campomanesia adamantium pulp in controlled environments. Food Chemistry, v.135, p.2960-2964, 2012. https://doi.org/10.1016/j.foodchem.2012.07.029

Brasil. Agência Nacional de Vigilância Sanitária. Resolução RDC n.269, de 22 de setembro de 2005, que dispõe sobre o Regulamento Técnico sobre a ingestão diária recomendada (IDR) de proteína, vitaminas e minerais. Brasília, DF: Diário Oficial da República Federativa do Brasil, 2005.

Campos, R. P.; Knoch, B.; Hiane, P. A.; Ramos, M. I. L.; Ramos Filho, M. M. 1-MCP em mangabas armazenadas em temperatura ambiente e a $11^{\circ} \mathrm{C}$. Revista Brasileira de Fruticultura, v.especial, p.206-212, 2011.

Carvalho, D. de M.; Takeuchi, K. P.; Geraldine, R. M.; Moura, C. J. de; Silveira, M. F. A. Filme ativo de acetato de celulose incorporado com nanosuspensão de curcumina. Polímeros, v.27, p.70-76, 2017. https://doi.org/10.1590/0104-1428.2232

FAO - Food and Agriculture Organization. Fruit and vegetable processing. Rome: Agricultural Services Division FAO, 1995. 249p.

Gava, A. J. Tecnologia de Alimentos: Princípios e aplicações. São Paulo: Editora Nobel, 2009.

Goula, A. M.; Adamopoulos, K. G. Effect of maltodextrin addition during spray dryin of tomato pulp in dehumidified air: I. Drying kinetics and product recovery. Drying technology, v.26, p.714725, 2008. https://doi.org/10.1080/07373930802046369
IAL - Instituto Adolfo Lutz. Normas analíticas do Instituto Adolfo Lutz: Métodos químicos e físicos para análise de alimentos. 4.ed. São Paulo: IAL, 2008. 1020p.

Jangam, S. V.; Law, C. L.; Mujumdar, A. S. Drying of foods, vegetables and fruits. Singapur: Universidade Internacional de Singapur, 2010. 232p.

Lisbôa, C. G. C. de; Figueirêdo, R. M. F. de; Queiroz, A. J. de M. Armazenamento de figo-da-índia em pó. Revista Brasileira de Engenharia Agrícola e Ambiental, v.16, p.216-221, 2012. https:// doi.org/10.1590/S1415-43662012000200013

Moreira, J. da S. de A.; Souza, M. L. de; Araújo Neto, S. E. de; Silva, R. F. da. Estudo da estabilidade microbiológica e físico-química de polpa de cupuaçu desidratada em estufa. Revista Caatinga, v.24, p.26-32, 2011.

Oikonomopoulou, V. P.; Krokida, M. K.; Karathanos, V. T. The influence of freeze drying conditions on microstructural changes of food products. Procedia Food Science, v.1, p.647-654, 2011. https://doi.org/10.1016/j.profoo.2011.09.097

Oliveira, A. da S.; Figueirêdo, R. M. F. de; Queiroz, A. J. de M.; Brito, J. G. de. Estabilidade da polpa do Cereus jamacaru em pó durante o armazenamento. Revista Brasileira de Engenharia Agrícola e Ambiental, v.19, p.147-153, 2015a. https://doi. org/10.1590/1807-1929/agriambi.v19n2p147-153

Oliveira, D. M.; Lima, C. G.; Clemente, E.; Afonso, M. R. A.; Costa, J. M. C. da. Stability of bioactive compounds and quality parameters of grugru palm powder (A crocomia Aculeata) in different drying conditions. Journal of Food Quality, v.38, p.94102, 2015b. https://doi.org/10.1111/jfq.12126

Perfeito, D. G. A.; Carvalho, N.; Lopes, M. C. M.; Schmidt, F. L. Caracterização de frutos de mangabas (Hancornia speciosa Gomes) e estudo de processos de extração da polpa. Revista de Agricultura Neotropical, v.2, p.1-7, 2015.

Ribeiro, L. C. Produção de acerola em pó: Métodos de secagem e avaliação da estabilidade. Fortaleza: UFC, 2014. 126p. Dissertação Mestrado

Sanjinez-Argandoña, E. J.; Branco, I. G.; Bittencourt, T. U.; Munhoz, C. L. Influência da geometria e da temperatura na cinética de secagem de tomate (Lycopersicum esculentum). Ciência e Tecnologia de Alimentos, v.31, p.308-312,2011. https://doi. org/10.1590/S0101-20612011000200005

Santos, A. F. dos; Silva, S. de M.; Mendonça, R. M. N.; Alves, R. E. Conservação pós-colheita da mangaba em função da maturação, atmosfera e temperatura de armazenamento. Ciência e Tecnologia de Alimentos, v.29. p.85-91, 2009. https://doi.org/10.1590/S010120612009000100014 
Sousa, S. L.; Morais, B. A. de; Ribeiro, L. C.; Costa, J. M. C. da. Stability of cashew apple juice in powder dehydrated in spouted bed. Revista Brasileira de Engenharia Agrícola e Ambiental, v.20, p.678-682, 2016. https://doi.org/10.1590/1807-1929/agriambi.v20n7p678-682 Statsoft. Statistica for Window - Computer programa manual. Versão 7.0. Tulsa: Statsoft Inc. 2007.

Strohecker, R; Henning, H. M. Analises de vitaminas: Métodos comprobados. 1.ed. Madrid: Paz Montalvo, 1967. 428p.
Teixeira, M; Monteiro, M. Degradação da vitamina c em suco de fruta. Revista Alimentos e Nutrição, v.17, p.219-227, 2006.

Tonon, R. V.; Brabet, C.; Hubinger, M. D. Influência da temperatura do ar de secagem e da concentração de agente carreador sobre as propriedades físico-químicas do suco de açaí em pó. Ciência e Tecnologia de Alimentos, v.29, p.444-450, 2009. https://doi. org/10.1590/S0101-20612009000200034 